\title{
A COMPARISON OF CHILD PSYCHIATRIC MORBIDITY IN AMERICAN AND BRITISH MILITARY FAMILIES OVERSEAS
}

\author{
Major R. S. BRITTON, M.B., D.P.M., D.T.M.\&H., R.A.M.C. \\ Assistant Professor of Psychiatry, Royal Army Medical College. \\ Major C. K. CORDES, M.D., M.C., U.S.A. \\ Consultant in Child Psychiatry to USAEUR.*
}

\begin{abstract}
SUMMARY: An attempt has been made to compare the relative incidence of various psychiatric disorders in British and American children by sampling consecutive cases seen in the primary child guidance clinics of the two countries' military forces in Germany. Certain significant differences-as well as similarities-were discovered, and some speculations have been offered to explain these.
\end{abstract}

\section{Introduction}

Cross-cultural psychiatry is very much in vogue and there has been endless speculation about the differences in frequency and types of psychiatric disorder in different societies. Much of the research has been descriptive or based on sociological or anthropologic surveys, rather than on the actual measurement and comparison of psychiatric disorders as they appear in different societies. Attempts to sample consecutive cases in two different psychiatric clinics in two separate countries can be easily criticized on the basis that such clinics function very differently in different places (even within one country), and two clinics may sample entirely non-representative population of each country. Yet the fascination with trying to compare remains. About one year ago it occurred to both authors that they had available to them two populations that might be easily and validly compared; the military communities of their respective countries (Britain and America) living overseas in the same foreign country (West Germany).

At the time of the study both authors were chiefs of the largest child psychiatric clinics of their respective armies in Germany: the British Military Hospital at Munster and the United States Army General Hospital at Landstuhl. One might hope that in comparing these two populations many variables which could otherwise invalidate such a study-different occupation, social class, attitudes toward going to psychiatric clinic, etc.-could be eliminated, and that the actual differences in psychiatric disorders in children in Britain and America could be identified. This is hardly an exhaustive study, but perhaps it may point the way toward more fertile speculation; if not more precise delineation of the differences.

\section{Method}

Consecutive unselected referrals to the two child guidance clinics previously mentioned were sampled, until 100 cases diagnosed as having a functional non-psychotic disorder (neurotic or conduct) were included in each sample. The only cases excluded from the study were those who had an inadequate evaluation (e.g. one visit to the clinic) or who were diagnosed as having no psychiatric disorder. The sample covered approxi-

* Now. Chief of Child Psychiatry, Walter Reed Army Medical Center, Washington D.C. 
mately the total referrals to the British clinic in 1967, and the referrals to the American clinic from October 1966 to June 1967. In order to obtain the basic sample of 100 neurotic and conduct disorders, 130 British and 134 American children were included in the original sample. The two samples were then compared in several areas. A standardised symptom list was developed and from the case files each child was recorded as manifesting one or more of these symptoms. Neurotic disorder was classified as a disorder with no more than one symptom of conduct disturbance in addition to neurotic symptomatology. Conduct disorder as a disorder in which symptoms of disturbed behaviour were not accompanied by neurotic symptoms. Mixed disorder was used to classify those children who showed both types of symptom.

\section{Results}

Sources of referral. The sources or methods of referral of the children to the child guidance clinics are listed in Table I. They were remarkably similar, particularly in the

Table I

Source or method of referral

\begin{tabular}{|c|c|c|}
\hline \multirow{2}{*}{ Source of Referral } & \multicolumn{2}{|c|}{ Nationality } \\
\hline & British & American \\
\hline $\begin{array}{l}\text { Paediatrician } \\
\text { General Practitioner } \\
\text { School } \\
\text { Adult Psychiatric Clinic } \\
\text { Ear, Nose and Throat Surgeon } \\
\text { Speech Therapist } \\
\text { Self referral } \\
\text { Chaplain } \\
\text { Health Visitor } \\
\text { Court } \\
\text { Other Child Guidance Clinics }\end{array}$ & $\begin{array}{r}17\} 72 \\
55 \\
41 \\
8 \\
3 \\
0 \\
0 \\
0 \\
4 \\
2 \\
0\end{array}$ & $\begin{array}{r}43 \\
28\} \\
33 \\
4 \\
4 \\
8 \\
12 \\
1 \\
0 \\
0 \\
1\end{array}$ \\
\hline Totals & 130 & 134 \\
\hline
\end{tabular}

total percentage of medical referrals. The American children were referred from a greater variety of sources and include a significant number of self (or parental) referrals.

Type of disorder. The remainder of the study concerns only the 100 children in each group diagnosed as suffering from a neurotic or a conduct disorder (Table II).

Table II

Types of disorder

\begin{tabular}{|c|c|c|}
\hline \multirow{2}{*}{ Type of disorder } & \multicolumn{2}{|c|}{ Nationality } \\
\hline & British & American \\
\hline $\begin{array}{l}\text { Neurotic or conduct disorder } \\
\text { Mental subnormality } \\
\text { Childhood psychosis } \\
\text { Adolescent schizophrenia } \\
\text { Physical defects (primarily deafness) }\end{array}$ & $\begin{array}{r}100 \\
21 \\
3 \\
0 \\
6\end{array}$ & $\begin{array}{r}100 \\
22 \\
3 \\
1 \\
8\end{array}$ \\
\hline Totals & 130 & 134 \\
\hline
\end{tabular}


Age. There was no significant difference between the two groups $\left(\mathrm{Chi}^{2}=1.52\right)$ (Table III).

Sex. There was no significant difference between the two groups (Chi ${ }^{2}=0.81$ ) (Table III).

Father's rank. The differences in the ranks of the fathers were highly significant $\left(\mathrm{Chi}^{2}=62.2: \mathrm{p}=.001\right)$ (Table III).

\begin{tabular}{|c|c|c|}
\hline & \multicolumn{2}{|c|}{ Nationality } \\
\hline & British & American \\
\hline $\begin{array}{l}\text { Age } \\
\text { Under } 6 \text { years } \\
6 \text { to } 11 \text { years } \\
12 \text { years and over }\end{array}$ & $\begin{array}{l}19 \\
56 \\
25\end{array}$ & $\begin{array}{l}13 \\
63 \\
24\end{array}$ \\
\hline $\begin{array}{l}\text { Sex } \\
\text { Boys } \\
\text { Girls }\end{array}$ & $\begin{array}{l}64 \\
36\end{array}$ & $\begin{array}{l}70 \\
30\end{array}$ \\
\hline $\begin{array}{l}\text { Father's rank } \\
\text { Officer } \\
\text { Senior non-commissioned officer } \\
\text { Junior rank }\end{array}$ & $\begin{array}{r}6 \\
32 \\
62\end{array}$ & $\begin{array}{r}22 \\
69 \\
9\end{array}$ \\
\hline
\end{tabular}

Diagnostic classification. Using the classification in the table the difference in the distribution of the American and British children between the three groups was statistically significant (Chi ${ }^{2}=15.32: \mathrm{p}=.001$ ) (Table IV).

Table IV

Diagnostic classification of 100 children in each group (neurotic or conduct disorder)

\begin{tabular}{l|c|c}
\hline \multicolumn{1}{c|}{ Diagnostic classification } & Nationality \\
\cline { 2 - 3 } & British & American \\
\hline Neurotic disorder & 30 & 35 \\
Mixed (neurotic and conduct) disorder & 51 & 26 \\
Conduct disorder & 19 & 39 \\
\hline
\end{tabular}

If the number of American and British children placed in the conduct disorder group is compared the difference between them is significant $\left(\mathrm{Chi}^{2}=9.714: \mathrm{p}=.01\right)$. Roughly twice as many of the American sample were placed in this category as in the British sample (British 19 : American 39).

Symptoms. The average number of symptoms per child was 6.09 for the British children and 5.26 for the American children (Table V). The difference in the frequency of each symptom in the two groups was tested using $\mathrm{Chi}^{2}$ with Yates correction where necessary. 
Table V

Symptom frequency compared and significance tested using Chi Squared

\begin{tabular}{|c|c|c|c|}
\hline Symptom & British & American & $\begin{array}{c}\text { Significance } \\
\mathrm{p}=\end{array}$ \\
\hline $\begin{array}{l}\text { Enuresis } \\
\text { Mood disorder } \\
\text { Defiance } \\
\text { Anxiety } \\
\text { Stealing } \\
\text { Temper tantrums } \\
\text { Learning difficulty } \\
\text { Jealousy } \\
\text { Sleep disorder } \\
\text { Restlessness } \\
\text { Lying } \\
\text { Aggressive behaviour } \\
\text { Phobias } \\
\text { Food fads } \\
\text { Timidity } \\
\text { Destructiveness } \\
\text { Separation anxiety } \\
\text { Encopresis } \\
\text { Tension habits } \\
\text { Withdrawal } \\
\text { Running away } \\
\text { Fire setting } \\
\text { School refusal } \\
\text { Panics } \\
\text { Tics } \\
\text { Sexual problems } \\
\text { Rituals } \\
\text { Compulsions } \\
\text { Obesity } \\
\text { Conversion hysteria } \\
\text { Pica } \\
\text { Attempted suicide }\end{array}$ & $\begin{array}{r}46 \\
45 \\
41 \\
40 \\
40 \\
36 \\
36 \\
30 \\
28 \\
27 \\
26 \\
23 \\
26 \\
24 \\
23 \\
22 \\
18 \\
18 \\
18 \\
17 \\
13 \\
11 \\
8 \\
5 \\
5 \\
5 \\
4 \\
2 \\
2 \\
1 \\
1 \\
1\end{array}$ & $\begin{array}{r}17 \\
31 \\
42 \\
53 \\
15 \\
41 \\
54 \\
8 \\
24 \\
27 \\
30 \\
28 \\
8 \\
6 \\
7 \\
11 \\
11 \\
6 \\
38 \\
23 \\
9 \\
3 \\
1 \\
2 \\
3 \\
16 \\
0 \\
4 \\
3 \\
0 \\
0 \\
3\end{array}$ & $\begin{array}{l}.001 \\
.05 \\
\text { N.S. } \\
\text { N.S. } \\
.001 \\
\text { N.S. } \\
.02 \\
.001 \\
\text { N.S. } \\
\text { N.S. } \\
\text { N.S. } \\
\text { N.S. } \\
.001 \\
.001 \\
.01 \\
.05 \\
\text { N.S. } \\
.01 \\
\text {.001 } \\
\text { N.S. } \\
\text { N.S. } \\
\text { N.S. } \\
.02 \\
\text { N.S. } \\
\text { N.S. } \\
\text {.05 } \\
\text { N.S. } \\
\text { N.S. } \\
\text { N.S. } \\
\text { N.S. } \\
\text { N.S. } \\
\text { N.S. }\end{array}$ \\
\hline
\end{tabular}

N.S. $=$ No significant difference.

Learning difficulty and tension habits occurred more often in the American group. Enuresis, encropresis, stealing, phobias, timidity, jealousy, food fads, and school refusal were significantly more common in the British sample. At a less confident statistical level $(\mathrm{p}=.05)$ sexual problems seemed to be more common in the American group, destructiveness and mood disorder in the British.

\section{Discussion}

The temptation is irresistible to compare these findings to a common stereotype of British and American children-a stereotype, one might add, that each country has of the other, not of itself. The American child is rowdy, undisciplined, defiant, a behaviour problem at home and in school, and not very concerned about his impact on others. The British child is timid, frightened, overpolite, uncreative, and the victim of a harsh system of regimentation of his feelings and his excretions.

This study seems to support some of the less extreme aspects of these stereotypes. The American children had a much higher incidence of conduct disorder. Their slightly higher incidence of neurotic disorder might seem to contradict this at first sight, but this requires a special explanation. The category of neurotic-conduct (mixed) disorder 
is not used in American psychiatry, and the American author perforce had to rediagnose cases into this category.

It seems likely that a number of the American children regarded as neurotic at the time of the initial assessment might have found their way into a mixed category had it existed. Minor symptoms of conduct disturbance such as jealous behaviour and petty destructiveness at home may have been ignored in the presence of more serious neurotic symptoms. This argument does not seem to apply in the same way to conduct disorder since in both clinics the presence of neurotic disturbance would have been used to exclude the children from this category or its American counterpart, "character and behaviour disorder", even at the time of assessment. It seems possible therefore that there may have been a real difference between the two groups in this respect: with the American children showing more conduct disorder and the British more neurotic disturbance. The only way to test this hypothesis would be to arrange for a prospective study, with both clinics using the same, more definitive diagnostic classification from the outset. It is hoped that this will be possible.

When considering individual symptoms, one of the most outstanding differences was the higher frequency of enuresis and encopresis in British children. Is this a result of harsher and earlier toilet training practices in Britain? The British children were also more phobic, more timid, had more school refusals, more food fads, and more mood disorders. American children had more learning problems in school and more sexual problems.

But in some areas the stereotypes break down. Destructiveness was actually more common in British children and other forms of acting-out behaviour - temper tantrums, defiance, lying, aggressive behaviour, running away, and firesetting -have essentially the same frequency in both groups. Overt anxiety was slightly more common in American children, tension habits much more so, and such "classically neurotic" symptoms as sleep disorders, separation anxiety, and withdrawal did not have any different incidence in the two groups. It is also difficult to explain the markedly higher frequency of stealing in British children. Another area of significant difference was the rank of father. The difference between the two groups of enlisted men is probably only reflective of the age differences and rank structure of the two armies (American enlisted men below sergeant's rank rarely have children, or at least, children beyond infancy). But the higher incidence of American officers' children is striking. American officers make up 11 per cent of the army, yet they comprise 22 per cent of the families. This figure, taken in conjunction with the higher American incidence of self-referrals, suggests that to seek psychiatric help in the American military service is more acceptable than in the British army: and that this willingness to seek help increases with rank (and social class). Does it actually decrease with rank in the British Army, or are the lower ranks more familiar with using the National Health Service, and this has helped them to accept psychiatric referral? One other intriguing possibility should be mentioned. Is it possible that we have measured only minor differences, because overseas military families of any country resemble each other more than they resemble their civilian counterparts in their own country? Kenny (1967) in a study comparing children attending an American Army child guidance clinic with the reports of clinics in the United States civilian population claims that the American service child is more neurotic and less delinquent than his civil counterpart. The impression amongst British army child psychiatrists is also that 
the military population overseas presents clinics with more neurotic and less delinquent problems than at home.

The polarisation of individual children into the neurotic or the sociopathic is a favourite device of those who study disturbed or delinquent children (Hewitt and Jenkins, 1946, Peterson, Quay and Tiffany, 1961). The implication is that these are two alternative expressions of disturbance. Also implied is that one or other response is favoured by different family and cultural patterns. Some work suggests that once established in childhood these " broad categories" persist into adult life, "whether the individual suffers or whether he causes others to suffer" (Pritchard and Graham, 1966).

Comparative studies offer an opportunity to test out some hypotheses in this field and it is hoped that more carefully controlled comparisons can be made between these two clinic populations in the future.

\section{REFERENCES}

HewitT, L. E. and Jenkins, R. L. (1964). "Fundamental Patterns of Maladjustment". D. H. Green, Michigan.

Kenny, J. A. (1967). J. Amer. Child Psychiat. 6, 51.

Peterson, D. R., Quay, H. C. and Tiffany, T. L. (1961). Child Develop. 32, 355.

Pritchard, M. and Graham, P. (1966). Brit. J. Psychiat. 112, 603.

\section{Senior Appointment}

Brigadier J. H. Robertson, Q.H.D.S., F.D.S., R.C.S., to be Director Army Dental Service in May 1970, with the rank of Major-General.

Brigadier Robertson was born on 16 October 1915. He was educated at the Whitehill School, Glasgow, and later graduated at the Glasgow Dental Hospital in May 1939. In 1957 he qualified as a Fellow in Dental Surgery of the Royal College of Surgeons, Edinburgh.

He was granted a short service commission in the Royal Army Dental Corps in 1939 and became a regular officer in 1945.

He has served in the Middle East, North-West Europe and the British Army of the Rhine. His senior appointments have been as Senior Specialist in Dental Surgery at the British Military Hospital, Dhekelia, Cyprus, the Military Hospital, Catterick and the Cambridge Military Hospital, Aldershot, his present appointment being as Consulting Dental Surgeon to the Army.

He was promoted Queen's Honorary Dental Surgeon in 1967, and Officer (Brother) in the Order of St. John of Jerusalem in 1969. 